This is the peer reviewed version of the following article: Antonioli, F., Ben Kaabia, M., Arfini, F., \& Gil, J. (2018). Price transmission dynamics for quality-certified food products: A comparison between conventional and organic fluid milk in Italy. Agribusiness, 35(3), 374-393. doi:10.1002/agr.21568 which has been published in final form at https://doi.org/10.1002/agr.21568. This article may be used for noncommercial purposes in accordance with Wiley Terms and Conditions for Use of SelfArchived Versions http://www.wileyauthors.com/self-archiving.

Document downloaded from: 


\title{
Price Transmission Dynamics for Quality-Certified Food Products. A Comparison between Conventional and Organic Fluid Milk in Italy
}

\begin{abstract}
Despite the vast number of works investigating price transmission processes in diverse agri-food markets, very little has been said about quality-differentiated products. In this paper, we compare the conventional and organic fluid milk sectors in Italy to better understand the economic organization and functioning of one of the most important agri-foods in Italy. Using a unique dataset featuring processor and retail (scanner) prices for the two types of milk, we estimate (M)TAR models to account for asymmetric price movements in both sectors, but the price transmission results are eventually symmetric. The VECM estimations and IRFs analysis provide significant insights into the differences between the two markets. [EconLit citations: Q130, Q110, C590 - Keywords: Fluid milk, Price Transmission, Organic vs. Conventional, Asymmetries]
\end{abstract}

\section{Introduction to the Study}

The analysis of price transmission (PT) mechanisms in food chains has attracted considerable interest among agricultural economists, mainly due to their welfare and policy implications. Price is the first link between economic agents, driving their strategic and structural decisions and giving a good measure of integration and thus chain dynamics (Abdulai, 2002; Goodwin and Holt, 1999; Lloyd, 2016; Serra and Goodwin, 2003).

Despite the increasing literature about price transmission, there is a lack of studies investigating PT for quality-differentiated agricultural markets; therefore, a comparison with their conventional counterparts cannot be made. Consumer demand for healthier, safer, environmentally friendly and premium-quality foodstuffs has recently increased. This has shaped food industry offerings, and quality-differentiated products bearing specific claims have become available (Unnevehr et al., 
2010). Among those, we focused on organic-labeled fluid milk. Indeed, the demand for organic food products is on the rise in Europe, with a market value estimated at 20.8 billion euros in 2012. EU policymakers have recognized the importance of this emerging market through supporting organic farming, in light of its contribution in producing public goods (Meredith et al., 2014). Furthermore, Italy represents the fourth-largest organic market in Europe, with more than 2 billion Euros of retail sales, and the second-largest in terms of both organic producers, with approximately 52 thousand operators, and organic land, with more than 1.4 million hectares in 2015 (Willer et al., 2017).

The objective of this study and its main contribution to the existing literature is to determine the price transmission mechanism of an organic food product, providing a comparison to its conventional counterpart and deepening the understanding of the economic organization and functioning of both markets. Although the Italian conventional fluid milk market has been the focus of several economic research papers in the last twenty years, few works have performed price transmission analyses, especially accounting for retail data prices. Distributors currently play a pivotal role in defining the functioning of the SC, channeling almost the entire households' food basket and potentially exerting market power upstream, thus shaping structural and strategic decisions of other agents. Both ends of the milk SC (i.e., milk producers and consumers) have often identified retailers as the source of market disruptions, undermining the functioning of the supply chain and narrowing the effects of the milk crisis on upstream players. Discovering the PT mechanism between industrial producers and distributors in the last twenty years has shed light on how prices are passed through, thus unveiling actors' behaviors and hence providing insights into operational and marketing strategies that they put in place. The recent increase in organic production in the milk sector reflects farmers' response to low margins and the high uncertainty that characterizes the conventional milk market, in addition to the sharp increase in consumer demand for organic food products. Moreover, the EU established a certification and labeling 
procedure for organic products, exploiting the premium price that consumers are willing to pay for these quality products. However, the PT literature lacks studies regarding this differentiated milk sector, highlighting the need for a deeper understanding of the functioning of such an essential branch of the agri-food sector. Quality-differentiated products usually entail shorter chains and different distribution channels, features expected to support different price transmission dynamics. The Italian fluid milk market has been chosen as the case study because it represents one of the most important agri-food sectors in Italy. The dairy industry is a major asset that is worth 15 billion euros, $11.5 \%$ of the food industry turnover, and has an employed workforce of approximately 30,000 people (Gonano and Mambriani, 2014). Moreover, Italy is the seventh-largest EU-28 milk producer, providing 7\% of total EU (cow) milk (EUROSTAT, 2017). Hence, the conventional fluid milk market represents the benchmark for comparison with organic price transmission dynamics.

A unique dataset provided by one of the most prominent Italian food distributors is used for the analysis; it includes processor and retail (scanner) prices for the two types of milk. These data yield insights into retailer marketing strategies for conventional and differentiated (i.e., organic) products. Indeed, price transmission studies largely use data for aggregate categories (e.g., dairy, meat, or apples), an approach that prevents generating robust results when the research objective concerns quality-differentiated products. Time-series econometrics is applied for investigating price transmission dynamics. The potential role of asymmetries is then explored through nonlinear univariate models. When linearity tests accept the null of linearity, a Vector Error Correction Model (VECM) is used to interpret long-run relationships, and Impulse Response Functions (IRFs) are used to understand short-run dynamics.

The work is organized as follows. Section 2 provides a brief analysis of the organic and conventional fluid milk sectors, whereas Section 3 illustrates the theoretical framework. Section 4 describes the type of data used and the applied methodological approach. Section 5 presents the empirical 
results for each system, whereas Section 6 provides a discussion of the results, and Section 7 concludes.

\section{The Organic and Conventional Fluid Milk Sectors in Italy}

The Italian dairy sector is undergoing a profound crisis, and organic production has grown tremendously as an instrument of differentiation and thus margin stabilization, representing a sort of safety net for troubled milk producers. Private dairy companies transform the raw milk delivered by farmers, producing $92 \%$ of the total fluid milk (ISTAT, 2018), which reaches consumers through retailers. In fact, modern distribution (MD) is currently the primary retail format in Italy, consisting of all those points of sale having large surfaces and self-service (AGCM, 2013) (see also Sckokai (2014) for a detailed classification of MD channels). According to the most recent data available, the $\mathrm{CR}(5)$ (Concentration ratio of the first five companies) of the MD channel is almost $50 \%$, with nearly $90 \%$ of household spending on fluid milk concentrated on this channel, justifying the concerns expressed by society and institutions over its impact on chain performance (Federdistribuzione, 2013). On the supply side, raw conventional milk production relies on 157 thousand dairy farms (with at least one bovine head), accounting for more than 4.6 million heads of cattle and producing more than 11 million of tons of raw milk. The total amount of fluid milk produced reached 2.4 million of tons in 2016 (ISTAT, 2018), with a sales value approximately 2.5 billion euros (Gonano and Mambriani, 2014). Compared to the numbers of the organic sector, the latter still represents a niche market within the Italian milk industry. Relying on the statistics provided by the Official Italian National Accreditation Body (ACCREDIA), there are 255 organic dairy farms currently active on the Italian territory and more than 57 thousand dairy cows. The total organic raw milk production achieved in 2015 was 215 thousand tons, of which 23.5 thousand tons were destined to fluid milk (statistics from SINAB - National Information System on Organic Farming). According to the Organic Data Network provided by Willer (2015), dairy products account for $18 \%$ of total organic sales, approximately 77 million euros, after fruits and vegetables (27\%). Within the category of dairies, 
fluid milk represents the second most-sold product after yogurts, with $34 \%$ of overall sales, approximately 27 million euros. Organic milk represents almost $2 \%$ of total milk sales and $3.5 \%$ of total milk production in Italy. Organic supply chains are usually regarded as short supply chains, that is, the number of actors involved, from production to retailing, is lower than in conventional agrifood chains. Upstream agents seem to be more organized since the constitution of producers' organizations (POs) has been widely promoted and boosted by the European Commission and, consequently, by the national government. Moreover, the distribution sector is more competitive, since the MD channel represents just $27.4 \%$ of total organic sales, with specialized organic shops accounting for the lion's share (45\%) (Romeo and Bteich, 2014). Accordingly, one might expect that retailers in the organic market have a lower market power, if any, as the supply is also quite concentrated. Organic distribution is heterogeneous and less concentrated than in the conventional fluid milk supply chain. Consequently, we would expect symmetric responses from processors and retailers after unanticipated supply and demand shocks with quicker responses and of a higher magnitude, since the more competition the market features, the closer the price transmission process should be to a full pass-through.

\section{Theoretical Framework}

In this section, we provide a simple theoretical framework to explain which type of relations exist between the industrial processors of milk and food distributors in terms of prices. Within each of the two chains, the product is considered homogeneous and produced on the Italian territory only, since it is a high-perishable product. Thus, we assume constant returns to scale ${ }^{1}$ and fixedproportion technology for both agents considered in the study (Sexton and Zhang, 2001). We consider a general (inverse) consumer demand function for the fluid milk at the retail stage,

$P_{r}=D\left(Q_{r}, X_{r}\right)$

\footnotetext{
${ }^{1}$ See the seminal paper of McCorriston et al. (2001) for the interaction between returns to scale and market power.
} 
where $Q_{r}$ is the quantity of product at the retail level, $X_{r}$ is an exogenous demand shifter, and $P_{r}$ is the price faced by consumer on the final market. Likewise, the (inverse) supply function of the industrial processor is defined as

$P_{p}=S\left(Q_{p}, X_{p}\right)$

where $Q_{p}$ is the quantity of milk delivered by farmers and $X_{p}$ is an exogenous supply shifter. We assume that both milk processors and retailers use a constant-return technology and that no substitution is permitted between the raw milk delivered to processors and the other input used in producing the final products. Following Verreth et al. (2015), we assume that industrial processors act as price leaders; hence, retailers take the industrial processor price as given. Consequently, industrial processors determine the quantity of milk to be processed, relying on retailer's behavior. Therefore, the retailer's profit is maximized as

$\max _{q_{i}^{r}} \pi_{i}^{r}=D\left(Q_{r}\right) q_{i}^{r}-S\left(Q_{p}\right) q_{i}^{p}-c_{i}^{r} q_{i}^{r}$

where $Q_{r}=\sum_{i=1}^{n} q_{i}^{r}$ and $c_{i}^{r}$ represents the costs sustained by the retailer in handling one unit of product. The first order condition of (3) is then given by ${ }^{2}$

$\frac{\delta \pi_{i}^{r}}{\delta q_{i}^{r}}=P_{r}+q_{i}^{r} P_{r}^{\prime}\left(Q_{r}\right) \frac{\delta Q_{r}}{\delta q_{i}^{r}}-P_{p}-c_{i}^{r}=0$

from which we can derive the elasticity notation as

$P_{r}=\frac{\eta_{r}}{\eta_{r}-\theta_{r}}\left(P_{p}+c_{r}\right) \Rightarrow P_{p}\left(Q_{r} \mid \eta_{r}, \theta_{r}, c_{r}\right)$

where $\theta_{r}=\frac{\delta Q_{t}^{r}}{\delta q_{i, t}^{r}} \frac{q_{i, t}^{r}}{Q_{t}^{r}}$ defines the conjectural elasticity of retailers, i.e., the degree of oligopoly power exerted at this level of the chain, whereas $\eta_{r}=\frac{\delta Q_{r}}{\delta P_{r}} \frac{P_{r}}{Q}$ represents the absolute value of the demand's price elasticity. The conjectural variation elasticity describes the exertion of market power by retailers on consumers, taking a value of 1 when the distributor acts as a monopolist and a value of 0 when the market is perfectly competitive (Achayra et al., 2011; Huang and Sexton,

\footnotetext{
${ }^{2}$ See Lloyd et al. (2006) and Sexton et al. (2007) for a detailed derivation process.
} 
1996; Sexton et al., 2007). In a competitive market, $\theta_{i}=0$; hence, $P_{r}=P_{p}+c_{r}$ in (5), i.e., the retail price is equal to the processor price plus a constant cost.

Since $\eta_{r}, \theta_{r}$ are fixed constants, one should expect that (5) implies pass-through of changes in $P_{p}$ into $P_{r}$, with a lower limit of $1, \frac{\partial P_{r}}{\partial P_{p}}=\frac{\eta_{r}}{\eta_{r}-\theta_{r}} \geq 1$. Moreover, this also implies the processor-retailer elasticity of PT to be less than 1, such that

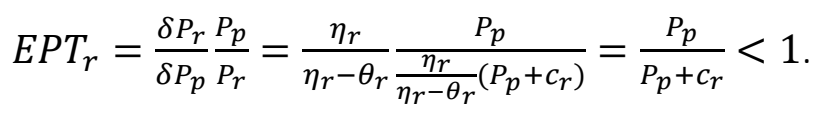

According to Kinnucan and Zhang (2015), EPT<1 is not inconsistent with the definition of competitive markets. Thus, a better test for imperfect competition concerns the slope of the price transmission relation. Specifically, because equation (6) implies that under imperfect competition $\frac{\delta P_{r}}{\delta P_{p}}>1$ (a one euro increase in wholesale price causes retail price to rise by more than one euro) rejection of $H_{0}: \frac{\delta P_{r}}{\delta P_{p}} \leq 1$ in favor of $H_{1}: \frac{\delta P_{r}}{\delta P_{p}}>1$ would constitute evidence of retailers' oligopoly power ${ }^{3}$.

The above framework, however, assumes price transmission symmetry, as does most of the theoretical literature. However, most of the recent empirical work has shown that asymmetries in price transmission (APT) are the general rule, not the exception. Peltzman (2000) was the first to generalize this idea, investigating a large number of markets and finding asymmetric behaviors in more than two of every three analyzed sectors. Indeed, a significant strain of the literature found APT, and several hypotheses have been explored by academics to explain such dynamics ${ }^{4}$. Retailers' $^{\prime}$ market power is the most frequently identified cause (see, among others, Bailey and Brorsen, 1989; Verreth et al., 2015; Borenstein et al., 1997; Lloyd et al., 2006; McCorriston et al., 2001; Sckokai et al., 2013; Sexton, 2013; Shrinivas and Gómez, 2016; Simioni et al., 2013), although further studies

\footnotetext{
${ }^{3}$ We would like to thank an anonymous referee for this useful comment.

${ }^{4}$ Meyer and von Cramon-Taubadel (2004) provide a thorough summary of the leading causes of asymmetry.
} 
(Acosta and Valdés, 2014; Bettendorf and Verboven, 2000; Peltzman, 2000; Serra and Goodwin, 2003) conclude that the exertion of market power and high concentration ratios are not fully consistent with asymmetries. Consumers' search costs may differ from one product to another, depending on the structure of the supply chain. In other words, only when price changes are higher than a certain level do consumers start their search in further retailers. That is, below a certain threshold, retailers are free to increase prices and hence margins, since consumers still perceive search costs as higher than the increased price (Borenstein et al., 1997; Ben Kaabia and Gil, 2007). Additional causes of APT have been debated, including substitutability between agricultural and other marketing inputs (Bettendorf and Verboven, 2000; McCorriston et al., 1998), adjustment costs (Azzam, 1999; Chavas and Mehta, 2004), product perishability (Santeramo, 2015; Santeramo and von Cramon-Taubadel, 2016; Ward, 1982), policy intervention (Brümmer et al., 2009; Cacchiarelli et al., 2016; Esposti and Listorti, 2013; Ihle et al., 2012; Kinnucan and Forker, 1987; Lee and Gómez, 2013; Santeramo and Cioffi, 2012), asymmetric information (Bailey and Brorsen, 1989) and inventory costs (Reagan and Weitzman, 1982). Tifaoui and von Cramon-Taubadel (2016) recently investigated the impact of the temporary sale price (TSP) on price transmission for butter in Germany, arguing that the "valleys" generated from TSP increase the speed and asymmetry of vertical price transmission. Recently, McLaren (2015) developed a theoretical framework to explain the existence of asymmetric price dynamics if there exist sufficiently convex marginal cost curves for market intermediaries, consistent with the monopsony power exerted by them. Investigating the relation between export intermediaries and farmers for a broad range of agricultural products and countries, he found that decreases in farm prices are far more completely passed to FOB prices than increases. Therefore, intermediaries use their market power to benefit from stretching margins, since they resell the agricultural product on the international market. Certainly, this logic can be applied to other types of market linkages between different agents (in our specific case, 
between food processors and retailers). One may expect the latter to exert market power and the so-called "rocket and feather" dynamics to occur (i.e., food-processor price increases are more fully and quickly transmitted to retail prices). According to McLaren (2015), the relation between retailer and industrial processor at the optimum can be specified as

$\overline{P_{r}}=w(\bar{Q})=w\left[\bar{Q}\left(P_{p}\right)\right]$

where $\bar{Q}\left(P_{p}\right)$ is the processors' supply function ${ }^{5}$, with $Q\left(P_{p}\right)^{\prime}>0$ and $Q\left(P_{p}\right)^{\prime \prime} \leq 0, w(\bar{Q})$ the inverse supply function of retailers, with $w(\bar{Q})^{\prime}>0$ and $w(\bar{Q})^{\prime \prime} \geq 0$, and $\bar{P}_{r}, \bar{Q}$ the retail price and quantity maximizing the profit, respectively (for the detailed methodology and derivation, see McLaren (2015)). The retail price is treated as exogenous, whereas the processor price is considered endogenous. Firms are assumed to be price takers in the retail market and to exert monopsony power for the processed product. One can evaluate the presence of asymmetry taking the second derivative with respect to $P_{p}$,

$\frac{d^{2} \overline{P_{r}}}{\left(d P_{p}\right)^{2}}$

If the latter is equal to zero, the transmission is symmetric. Restrictions are put on both supply functions' shapes, resulting in (7) having a negative sign and hence producing a concave relationship between the two levels of the chain. Indeed, given the highly perishable nature of fluid milk, one should expect negative asymmetries ${ }^{6}$ to exist, with retailers fearing spoilage (i.e., a $1 \%$ decrease in processor price is more fully passed to the retail price, Ps, than is an increase) (see diagram A in Figure 1). However, a different assumption about the marginal cost curve may be set, since one rather expects positive instead of negative asymmetries. The marginal cost curve would become steeper, losing convexity and modifying the relationship between the two prices, which turns convex (see diagram B in Figure 1).

\footnotetext{
${ }^{5}$ Summing over all processors' individual supply functions $q_{i}^{s}=q_{i}\left(P_{p, i}\right)$, with $q_{i}\left(P_{p, i}\right)^{\prime}>0, q_{i}\left(P_{p, i}\right)^{\prime \prime} \leq 0$.

${ }^{6}$ According to Meyer and von Cramon-Taubadel (2004), positive asymmetries exist whenever the system responds faster to squeezing- rather than stretching-margin situations. Negative asymmetries occur when the opposite situation exists.
} 
[Figure 1 about here]

Most recent studies about dairy and fluid milk markets have obtained mixed results. Analyzing dairy products in Austria, Amador et al. (2010) demonstrate the existence of positive asymmetries between producer and retail levels, characterized by a higher degree of concentration. The same results were obtained in Capps and Sherwell (2007) and Zeng and Gould (2016) in their studies regarding fluid milk market in the US and in Bakucs et al. (2012) concerning Poland. On the other hand, Acosta and Valdés (2014) found that negative asymmetries exist in the Panama dairy sector, which experienced an increased concentration level in recent years. Likewise, the results of Awokuse and Wang (2009) regarding milk price transmission in the U.S. indicated negative asymmetries. Serra and Goodwin (2003) found symmetric adjustment in highly perishable dairy products in Spain despite a highly concentrated retail level. Concerning the Italian fluid milk sector, Cavicchioli (2013) and later Madau et al. (2016) detected the exertion of market power from retailing toward farmers along the fluid milk supply chain. The results obtained by Sckokai et al. (2013) in their study regarding Parmigiano Reggiano and Grana Padano cheeses in Italy (the two major products of the quality-certified dairy industry) provide no evidence of market power from retailer toward processors, whereas there are signs of market power toward consumers. Table 1 summarizes the results obtained in the most recent works regarding price transmission in the fluid milk market.

[Table 1 about here]

\section{Modeling Asymmetric Price Transmission}

The presence of cost frictions may entail thresholds in the price transmission mechanism (BenKaabia and Gil, 2008; Lee and Gómez, 2013; Meyer, 2004), and only when deviations exceed the threshold(s) is an adjustment triggered (Abdulai, 2002; Balke and Fomby, 1997; Goodwin and Holt, 1999; Meyer and von Cramon-Taubadel, 2004). Different market structures and product 
characteristics involve different search and information costs for consumers, so threshold models may provide a more suitable modeling technique to account for these types of cost frictions.

The Threshold Autoregressive (TAR) model was first discussed by Tong (1983) and later revisited by Enders and Granger (1998), who introduced a model variation, the Momentum-TAR (M-TAR), increasing the model's popularity since then (for recent research in agricultural economics applying a TAR framework, see Abdulai (2002), Lee and Gómez (2013), Simioni et al. (2013), Goychuk and Meyers (2014), Tekgüç (2013), Awokuse and Wang (2009), Surathkal et al. (2014) and Han et al. (2016), among others). Engle and Granger (1987) showed that when two variables are cointegrated, an Error Correction Model (ECM) can be specified as

$\Delta \mathrm{p}_{1 \mathrm{t}}=\Phi_{\mathrm{j}}\left(\mathrm{p}_{2, \mathrm{t}-1}-\beta_{0}-\beta_{1} \mathrm{p}_{2, \mathrm{t}-1}\right)+\sum_{\mathrm{i}=1}^{\mathrm{k}-1} \Gamma_{\mathrm{i}} \Delta \mathrm{p}_{1, \mathrm{t}-\mathrm{i}}+\sum_{\mathrm{i}=1}^{\mathrm{k}-1} \delta_{\mathrm{i}} \Delta \mathrm{p}_{2, \mathrm{t}-\mathrm{i}}+\varepsilon_{\mathrm{t}}$

where $p_{i, t}, i=1,2$ are prices at two different levels of the supply chain, $\beta_{0}$ is a constant term, the term inside the brackets specifies the error correction mechanism (i.e., ECT), $\Gamma_{\mathrm{i}}$ and $\delta_{\mathrm{i}}$ are matrices of short-run parameters estimating the effect of shocks on $\Delta \mathrm{p}_{\mathrm{i}, \mathrm{t}}$, and $\varepsilon_{\mathrm{t}}$ is a disturbance term i.i.d. $\sim \mathrm{WN}\left(0, \sigma^{2}\right)$. Concerning the TAR approach, Enders and Granger (1998) specified an alternative error correction specification, arguing that in the presence of asymmetries, the twosteps Engle and Granger approach was misspecified. Therefore, they specified the error correction term as

$\Delta \widehat{\mu}_{t}=\left\{\begin{array}{l}\rho_{1} \hat{\mu}_{t-1}+\varepsilon_{t} \text { if } \hat{\mu}_{t-1} \geq \tau \\ \rho_{2} \hat{\mu}_{t-1}+\varepsilon_{t} \text { if } \hat{\mu}_{t-1}<\tau\end{array}\right.$

where $\Delta \widehat{\mu_{t}}$ is the differenced ECT, $\tau$ represents the threshold value (i.e., zero in this case), and a necessary condition for $\left\{\hat{\mu}_{t}\right\}$ to be stationary is that $-2<\left(\rho_{1}, \rho_{2}\right)<0$. A formal method to quantify the adjustment process is

$\Delta \widehat{\mu_{t}}=\mathrm{I}_{\mathrm{t}} \mathrm{p}_{1} \hat{\mu}_{\mathrm{t}-1}+\left(1-\mathrm{I}_{\mathrm{t}}\right) \mathrm{p}_{2} \hat{\mu}_{\mathrm{t}-1}+\varepsilon_{\mathrm{t}}$ 
where $I_{t}$ is the Heaviside indicator function $I_{t}=\left\{\begin{array}{ll}1 & \text { if } \hat{\mu}_{t-1} \geq \tau \\ 0 & \text { if } \hat{\mu}_{t-1}<\tau\end{array}\right.$. Whenever the system is convergent, $\widehat{\mu_{t}}=0$, whereas when $\hat{\mu}_{t-1}$ is above (below) its equilibrium value, the adjustment is $p_{1} \hat{\mu}_{t-1}\left(p_{2} \hat{\mu}_{t-1}\right)$. Accordingly, the error correction representation in (9) can be specified as

$\Delta p_{1 t}=I_{t} p_{1} \hat{\mu}_{t-1}+\left(1-I_{t}\right) p_{2} \hat{\mu}_{t-1}+\sum_{i=1}^{k-1} \Gamma_{i} \Delta p_{1, t-i}+\sum_{i=1}^{k-1} \delta_{i} \Delta p_{2, t-i}+\varepsilon_{\mathrm{t}}$

The MTAR specification described in Enders and Granger (1998) consists of adding lagged changes to the $\left\{\hat{\mu}_{t}\right\}$ process, such that Equation (12) can be now expressed as $\Delta \widehat{\mu_{t}}=I_{t} p_{1} \hat{\mu}_{t-1}+(1-$ $\left.I_{t}\right) p_{2} \hat{\mu}_{t-1}+\sum_{i=1}^{k-1} \gamma_{i} \Delta \hat{\mu}_{t-1}+\varepsilon_{\mathrm{t}}$. Accordingly, the Heaviside indicator can be now specified as $I_{t}=\left\{\begin{array}{ll}1 & \text { if } \Delta \hat{\mu}_{t-1} \geq 0 \\ 0 & \text { if } \Delta \hat{\mu}_{t-1}<0\end{array}\right.$. The latter model is preferred when a series exhibits more "momentum" in one direction. Regarding the estimation of the threshold, there is no theoretically based argument for assuming a zero threshold a priori (Simioni et al., 2013), hence Chan's (1993) technique, which estimates a super-consistent threshold is applied. However, it is first necessary to test the existence of threshold cointegration (i.e., $H_{0}: \rho_{1}=\rho_{2}=0$ ), and only when the null hypothesis is rejected in favor of threshold cointegration is asymmetric adjustment necessary (i.e., $H_{0}: \rho_{1}=\rho_{2}$ ).

\section{An Application to the Italian Conventional and Organic Fluid Milk System}

The dataset for each conventional and organic market is composed of 170 monthly observations covering the period of 2001-2015 (see Figure 2). Prices are expressed in $€ /$ liter, defining the amount paid (per unit of product) by retailers to processors (purchasing or processor price, $P_{p}$ ) and the price paid by consumers on the final market (selling or consumer price, $P_{S}$ ). The series were transformed into their logarithmic forms, mitigating the fluctuations and increasing the likelihood of stationarity after first differencing (Hamilton, 1994). Unit-root tests were used to interpret the stochastic properties of the series, for identifying non-stationary series and for selecting the right determinist term(s) for accurate modeling.

[Figure 2 about here] 
After excluding the presence of a trend, a constant was included when testing for unit-root ${ }^{7}$, since this improves the stability of results and, particularly for price transmission analysis, accounts for the current margin between prices over time. The Phillips-Perron (PP) (Phillips and Perron, 1988), the Generalised Least Square-Augmented Dickey-Fuller (GLS-ADF) (Elliott et al., 1996) and the KPSS (Kwiatkowski et al., 1992) tests for unit-root were applied ${ }^{8}$. All the unit-root tests conducted on the two price systems led to the conclusion that the series are I(1) (see Table 1A in the Appendix). When the same battery of unit-root tests was applied to variables in first differences, they proved to be $I(0)$, confirming that the series are (stochastic) difference stationary processes.

\subsection{Long-Run Relationships}

Since all prices are $I(1)$, the following step consists of testing for cointegration for each pair of prices within each system. Regarding the organic market, to appropriately model price transmission, four impulse dummy variables were included, accounting for atypical spikes, taking the value of 1 for October 2007, February 2008, January 2013 and June 2014 and 0 otherwise. Likewise, due to a break in the mean of the series in the period of March 2005 - May 2012, a shift dummy was included. Bearing in mind that the data refer to a single private economic agent, atypical behaviors along the series could have been triggered by economic events caused by private agreements between the parties involved, thereby preventing complete understanding of series' dynamics. The AIC (Akaike Information Criterion) suggested a VAR(7), and the Johansen (1988) cointegration test was applied accordingly (see Table 2), restricting both the constant and the shift dummy to the cointegration space:

$\Delta \mathrm{P}_{\mathrm{t}}=\alpha\left(\beta^{\prime} \mathrm{P}_{\mathrm{t}-1}+\mu_{1}^{\prime}+D_{s, t}\right)+\sum_{\mathrm{i}=1}^{\mathrm{k}-1} \Gamma_{\mathrm{i}} \Delta \mathrm{P}_{\mathrm{t}-\mathrm{i}}+D_{i, 1}+D_{i, 2}+D_{i, 2}+D_{i, 3}+D_{i, 4}+\varepsilon_{\mathrm{t}}$,

\footnotetext{
${ }^{7}$ The $\mathrm{F}$ test statistics for linear restrictions: $\beta=0, \gamma=0$ in the ADF regression $\Delta \Upsilon_{t}=\alpha+\Upsilon_{t-1}+\beta t+\sum_{j=1}^{p} \gamma_{j} \Delta \Upsilon_{t-j}+$ $\varepsilon_{\mathrm{t}}$ were 3.62 and 3.68 for conventional and organic milk, respectively, which are less than the C.V. at 5\% $6.49\left(\Phi_{3}\right)$. See Dickey and Fuller (1981) for further details.

${ }^{8}$ The standard ADF (Dickey and Fuller, 1979, 1981) and the PP tests suffer from low power and size distortions, leading to over-reject the hypothesis of unit root (DeJong et al., 1992; Ng and Perron, 2001; Schwert, 1989). To overcome such limitations and provide reliable results, we use the KPSS and the GLS-ADF jointly with the PP tests. See Table 1A in the Appendix for detailed results of the unit-root tests performed.
} 
where $\mu_{1}^{\prime}$ and $D_{s, t}$ are deterministic terms restricted to the cointegration space, namely, the constant and the shift dummy, respectively, the $D_{i, \mathrm{~m}}, m=1,2,3,4$ are dummy variables, as described above, $\alpha$ is the so-called loading matrix, and $\beta^{\prime}$ is the long-run coefficient.

[Table 2 about here]

Since the $\lambda_{\text {trace }}$ accepted one cointegrating relationship, whereas $\lambda_{\max }$ did not, the Engle and Granger (1987) methodology was also applied. The results clearly indicate the two prices share a long-run equilibrium relationship ${ }^{9}$ as follows: $\mathrm{P}_{\mathrm{s}}=0.39+0.53 \mathrm{P}_{\mathrm{p}}+0.03 \mathrm{D}_{\mathrm{s}, \mathrm{t}}+\hat{\mu}_{\mathrm{t}}$, where $\mathrm{D}_{\mathrm{s}, \mathrm{t}}$ represents the shift dummy.

When considering the conventional fluid milk supply chain, the same methodological steps as above were adopted. The graphical inspection suggests the presence of a structural break in the series around March 2010 and four major price spikes, for which four impulse dummies were modeled accordingly $^{10}$. Relying on the AIC, four lags have been included, and a VAR(4) was specified ${ }^{11}$. The results of the Johansen test indicated that we failed to reject the null of no cointegration. Hence, as suggested by Juselius (2006), we split the sample into two sub-samples, since structural breaks may invalidate the assumption of constant parameters. Given the date of the structural change, the two new specimens were defined for the periods of January 2001-February 2010 and March 2010February 2015. Regarding the first sub-sample, a VAR(2) was specified according to the AIC, and a constant was restricted to the cointegrating vector as

$$
\Delta \mathrm{P}_{\mathrm{t}}=\alpha\left(\beta^{\prime} \mathrm{P}_{\mathrm{t}-1}+\mu_{1}^{\prime}\right)+\sum_{\mathrm{i}=1}^{\mathrm{k}-1} \Gamma_{\mathrm{i}} \Delta \mathrm{P}_{\mathrm{t}-\mathrm{i}}+\varepsilon_{\mathrm{t}}
$$

Neither $\lambda_{\text {trace }}$ nor $\lambda_{\text {max }}$ indicated evidence of cointegration; accordingly, a VAR in first differences was specified. For the second sub-sample, a VAR(3) was specified based on the AIC, and a constant

\footnotetext{
${ }^{9}$ The Engle-Granger test did not accept the null of non-stationary residuals, with a p-value of 0.006 (Tau-statistic: 3.564).

${ }^{10}$ The four impulse dummies were $D_{i, m}=1, m=1,2,3,4$ for 2006:01, 2008:04, 2008:12, and 2010:03, respectively, and zero otherwise.

${ }^{11}$ For the model specification, see (13).
} 
restricted to the cointegrating space was employed ${ }^{12}$. The results from Johansen's $\lambda_{\text {trace }}$ and $\lambda_{\max }$, indicated the existence of one cointegration relationship (Table 2), which has the following expression: $\mathrm{P}_{\mathrm{s}}=0.28+0.72 \mathrm{P}_{\mathrm{p}}+\hat{\mu}_{\mathrm{t}}$.

As discussed in Section 3, non-linear asymmetries have been proved to be quite common behavior for a large number of agricultural markets at present, including dairy products. Accordingly, TAR and M-TAR models were considered using the residuals from the two estimated long-run equilibrium relationships detailed above (see Table 3). Concerning the organic system, both the AIC and SBC (Schwarz-Bayesian Criterion) indicated the need to include seven lags for $\Delta \hat{\mu}_{t-1}$ to exclude any autocorrelation from residuals. Although point estimates for $\rho_{1}$ and $\rho_{2}$ indicate convergence, i.e., they are all negative and satisfy the condition $\left(1+\rho_{1}\right)\left(1+\rho_{2}\right)<1$, the $\Phi$ and $\Phi^{*}$ coefficients failed to reject the null hypothesis of no-cointegration. Therefore, neither threshold cointegration nor asymmetric mechanism were detected regarding the organic fluid milk supply chain (see the fourth and fifth rows in Table 3, respectively). Likewise, the conventional market is well described by a symmetric transmission mechanism, since we fail to reject the null of no cointegration (see the tenth and eleventh rows in Table 3).

[Table 3 about here]

To ensure that the linear model is superior to the nonlinear one, the Hansen (1999) linearity test was employed. According to results of the performed linearity tests ${ }^{13}$, price transmission dynamics for both the organic and conventional systems were estimated via linear VECM(6) and VECM(2), respectively. The performed misspecification tests (see Doornik and Hendry, 1997) showed satisfactory results for both.

Table 4 reports the estimates of both cointegrating vectors, in addition to hypothesis tests on long and short-run parameters and on the slope of the price transmission relationship. Although the

\footnotetext{
${ }^{12}$ For the model specification, see (14).

${ }^{13}$ We tested the residuals for the presence of autocorrelation (Breusch-Godfrey Test), ARCH effects (Multi-ARCH LM), and normal distribution (Jarque-Bera) (the results are available upon request).
} 
parameter $\beta$ is usually referred to as the long-run price transmission elasticity ${ }^{14}$, Lütkepohl and Reimers (1992), and most recently Lloyd et al. (2006, p. 129), argue they are "[...] by construction partial derivatives predicated on the ceteris paribus assumption", and when richer dynamics occur (i.e., there is a feedback system in terms of causality), such inferences may be not of interest. Moreover, Kinnucan and Zhang's (2015) work heavily contributes to the idea that a price transmission elasticity equal to one does not mean perfect transmission, with this statement being inconsistent with the model of Gardner (1975). These authors showed that if the price changes are caused by shocks on the supply side (i.e., the industrial processor in our specific case), the PT elasticity (EPT hereafter) has to be less than one. Indeed, as clearly proved by Kinnucan and Zhang (2015), for EPT=1 to hold, the retail-demand and the processor-supply curves must have the same elasticity, which would be quite unusual and against the literature's findings regarding agricultural supply elasticity. Hence, both the long-run price transmission expressed as the percentage change and the slope were estimated by using natural logarithms and natural numbers, respectively, for both markets. Analyzing the first row of Table 4, concerning the quality-differentiated milk market, the unrestricted cointegrating vector is reported, characterized by a $\beta$ estimate of $51 \%$. As indicated in the third row, there is no long-run price homogeneity $[\beta(1,-1)]^{15}$, so when a $1 \%$ change on the processor price occurs, the transmission of such shocks to the retail price is not perfect but rather smaller.

In any case, as mentioned in Section 3, we cannot provide very useful economic insights because price transmission elasticity less than one is compatible with different market structures. To work with slopes, complementarily, we have estimated the model in nominal prices to test whether the

\footnotetext{
${ }^{14}$ See, among others, Abdelradi and Serra, 2015; Ben-Kaabia and Gil, 2007, 2008; Brümmer et al., 2009; Busse et al., 2012; Conforti, 2004; Goychuk and Meyers, 2014; Hassouneh et al., 2015; Listorti and Esposti, 2012b; Simioni et al., 2013; Tekgüç, 2013; and Verreth et al., 2015.

${ }^{15}$ After normalizing on consumer price, the process is (just-)identified, and further (non-identifying) restrictions on short and long-run parameters are imposed to enable economic interpretability of the results. Because the restrictions are asymptotically $\chi^{2}(v)$ distributed, with $v$ the number of imposed restrictions, the LR statistic is adequate for testing.
} 
slope is equal one. The results indicate that the null hypothesis of unity cannot be rejected ( $p$ value $=0.092)$; hence, the organic market is characterized by competitive behavior ${ }^{16}$.

[Table 4 about here]

Regarding short-run parameters, weak-exogeneity test on the load matrix indicates the $P_{\mathrm{P}}$ is weakly exogenous (see fifth row), and a cost-push mechanism well describes the dynamic of price transmission. Since the null hypothesis could not be rejected, the processor price does not adjust to deviations in the long run and all the adjustment falls on the retail price. The coefficient $\alpha_{\operatorname{Pr}}=$ -0.05 features a quite slow error correction, i.e., $5 \%$ each period, taking around twenty months to resettle into the steady state.

Opposite to its counterpart, the conventional milk sector is characterized by perfect long-run price homogeneity. Every percentage change in the processor (retailer) price generates a percentage change of the same size and direction in the consumer (processor) price. On the other hand, when testing for the slope of the PT relationship using prices in nominal values, the null of a slope equal to one is rejected ( $p$-value $=0.001)$, discarding the idea of a competitive system. Analyzing short-run parameters, only the retail price adjusts to deviations in the long run (i.e., cost-push mechanism), since the processor price proves weak-exogeneity. Exploiting the perfect transmission relationship, when prices are expressed in their natural logarithms, we restricted the cointegrating on the longrun price homogeneity. The constant did not vary significantly, whereas the $\alpha_{P S}$ moved from -0.38 in the unrestricted case to -0.20 in the restricted one, decreasing by nearly $50 \%$; hence, the retail price adjusts $20 \%$ of the disequilibrium in each period. The retailer's mark-up on the processor is given by the equation of Tiffin and Dawson (2000), as reported in the last row of Table 4. Given that the average percentage margin for the second sub-sample approaches $24 \%$, such results are

\footnotetext{
${ }^{16}$ The literature assumes marketing costs as constant, whereas one may argue this is not a realistic assumption considering a fifteen years period. As described by Kinnucan and Zhang (2015), omitting marketing costs in the estimating equation results in attenuation bias in the pass-through rate. Generally, it is assumed to be biased towards zero, prejudicing the test in favor of perfect competition hypothesis. Hence, caution needed when interpreting results (we are grateful to an anonymous referee for raising this point).
} 
consistent. However, no data concerning the cost structure of retailers are available, so no further comments on such results can be made. Moreover, this would go beyond the scope of this work.

\subsection{Short-Run Dynamics}

Impulse Response Functions were computed to gain more insights into the short-run dynamics of both investigated markets. These reveal price responses to an unexpected shock to the system. When the $\operatorname{VECM}(p)$ is stable, responses are represented as a Moving Average (MA) process, where the MA coefficient matrices contain the IRFs. Nevertheless, the residuals' variance and covariance matrices are non-diagonal, invalidating the assumption that shocks occur in just one variable, which may generate a misleading picture of existing dynamic relations. In other words, there exists contemporaneous correlation within the system. For this reason, orthogonalized IRFs (i.e., making the error terms uncorrelated) are preferred; they are obtained through the Wald decomposition of the MA representation (Lutkepohl, 2005). The orthogonal IRFs have been normalized on the estimate at time 'zero' of the impulse variable, and the ordinate axis displays the unit change (Figure 3). IRFs represent a good indicator of price dynamics along the supply chain.

[Figure 3 about here]

Regarding the organic system, the own-price response to shock on the processor side is positive and significant, as expected, and it persists significantly up to the $19^{\text {th }}$ period. The retail price positively responds after two months, with the response lasting until the $8^{\text {th }}$ month. The system then reaches a new equilibrium, and all prices respond significantly to any shocks. Own response to shocks on the consumer side, is, again as expected, positive and significant until the $16^{\text {th }}$ period. The response of processor price is positive and significant starting from the third month, overcoming the initial shock and reaching its maximum after seven periods. After reaching the apogee, it starts decreasing and lasts significantly until the $11^{\text {th }}$ month. Finally, since the magnitude of the response is greater when a shock occurs on the demand-side, a demand-pull mechanism seems to explain price transmission behavior in the organic sector better. 
Considering conventional milk, especially for the first sub-sample, all the computed IRFs were nonsignificant, and prices move independently of one another ${ }^{17}$ (according to IRFs results, the system was not cointegrated). However, regarding the second sub-sample, when a shock occurs on the offer side, both prices return to the steady state after approximately eight months. However, only the response of processor is significant and positive, and only for the first quarter, after which it starts decreasing and becomes negative, co-moving again with the retailer price. The retailer price, however, does not show any statistically significant response, although it displays a very moderate and positive response for the first four months and later becomes negative. When the shock is on the demand side, the own price response is quick and positive and reaches equilibrium after about eight months. Likewise, $P p$ reacts positively but becomes significant only after four months.

\section{Discussion}

A comparison between the two fluid markets reveals some significant differences. First, for the organic supply chain, the results showed a more responsive market than the conventional one, since cointegration has been found for the whole period. When the conventional fluid milk market is considered, prices started to co-move only from 2010. Indeed, for the preceding period, the results suggest that prices at the retail (processor) level are mainly determined by the retail (processor) supply and demand, not by the price paid to processors (sold at the retail level). Therefore, any unexpected shock occurring on any side of the chain is not transmitted either upstream or downstream. The comparison of results from each market indicates that the elasticity transmission and the speed of adjustment parameters are higher in the conventional market when logarithms are considered (the speed of adjustments after an unexpected shock in the organic market is four times less than in the conventional counterpart, and there is no evidence of long price homogeneity). Nevertheless, when prices at their natural levels are used in the estimation of the price dynamics, the quality-differentiated milk sector is revealed to be a competitive market

\footnotetext{
${ }^{17}$ Because of space limitations, IRF figures are not presented here but are available on request.
} 
since the slope of the relationship between the two prices is equal to one ${ }^{18}$. Different market structures between the organic and conventional sectors influence the mechanism of price passthrough. Whereas supermarkets and hypermarkets concentrate a significant share of the final demand for conventional fluid milk, in the case of the organic product, alternative marketing channels play a much more relevant role, reducing the market share of supermarkets and hypermarkets. Borrowing the hypothesis number three in Borenstein et al. (1997), we can argue that search costs for the organic milk consumer are higher, in the sense that when prices change, the expected gain from searching other distributors is smaller than for their conventional counterpart. Therefore, this may reduce (temporarily) the elasticity of the consumer demand and dampen the speed of adjustment. The still-limited awareness of the consumer of organic food, in general terms, together with a still-restricted access to information for this niche market could explain such a higher search cost. Moreover, because informal distributors (i.e., farmers' markets and direct sales) represent a significant part of organic-food retailing, the consumer may have to engage in intense research to understand whether price changes are due to market conditions or simply marketing strategy.

The short-run dynamics show that for the organic system, an increase in the consumer price causes a larger increment on the processor side; this result suggests that supply is inelastic (as expected, an increase on the demand side produces a larger increase on the production side, since the quantity produced is fixed in the short run), and upstream chains are better organized. Organic milk producers are fewer in number, improving their bargaining power and allowing for a better management on the supply side, thus improving the capability for coping with adverse market situations. Moreover, the processor reacts quicker than in the conventional case, and the magnitude of the response is significantly higher. When shocks occur on the supply side, the

\footnotetext{
${ }^{18}$ See footnote 16.
} 
consumer price response is significant, and a new equilibrium is reached. Changes in regulations, production methods or quality standards affect the cost-structure of producers, and shocks may become permanent.

In the conventional fluid milk market, after 2010, we observe a certain stickiness in the retail price, which may reflect the fact that when shocks occur on the supply side, the retailer absorbs the shock without transmitting it to the customer. They then most likely exert market power to pressure the processor to lower their selling price, which explains the rapid decrease of processor response. When demand-side shocks occur, the retailer tends to increase the volume purchased, causing an increase in processor price and a quick decrease in consumer price. Since supply shortages of fluid milk are exceptional, we consider here only positive shocks due to an increase in demand. The delay in processor response may be a consequence of private agreements; for instance, only when the milk spot price exceeds a certain threshold, previously agreed by the two actors, does the price paid to processors increase, since the processor cost structure changes substantially ${ }^{19}$. The most recent studies regarding the fluid milk sector many often conclude the price transmission dynamics is asymmetric (see Table 1). Nevertheless, our results are consistent with those of Serra and Goodwin (2003) for the Spanish market, whose characteristics are quite similar to those of the Italian sector and with those of Bakucs et al. (2012) for Hungary. Because fluid milk a low value-added product, this could prevent APT and tighten relationships between industrial processors and retailers (Serra and Goodwin, 2003). However, as indicated in Table 1, this comparison must be performed cautiously: each study is country-specific, and the vertical relationship investigated varies across studies, as does the direction of causality. Considering the speed of adjustment (see the last column in Table 1), it is distributed within a quite wide band, from $2 \%$ to $39 \%$ of shock transmitted in one period. One might say the speed is strongly dependent on the market structure and agent

\footnotetext{
${ }^{19}$ The SPOT milk price is the reference price for crude milk at the farm gate in Italy, i.e., the reference price for farmers.
} 
characteristics. Accounting for this, the two speeds of adjustment that we found for the conventional and the organic milk sector in Italy are within the band ( $20 \%$ and $5 \%$, respectively), despite the fact that organic milk prices have yet to be considered in any study, to the authors' knowledge. According to Serra and Goodwin (2003), Peltzman (2000), and Santeramo and von Cramon-Taubadel (2016), highly perishable products reveal a (more) symmetric PT mechanism. Kim and Ward (2013) and Ward (1982), despite both finding APT for perishable products, describe how retailers may be reluctant to increase prices, fearing sales reduction and hence increased spoilage.

\section{Conclusions}

The main objective (and contribution) of this paper was to determine price dynamics in a qualitydifferentiated market in relation to its conventional counterpart. The organic fluid milk market was used as a case study. The methodological approach was based on time series econometrics, with a special focus on asymmetric price dynamics.

The results suggest a number of points. First, in the case of the Italian fluid milk market (either organic or conventional), price reactions to unanticipated supply and demand shocks are symmetric, mainly for two reasons: i) the monthly frequency of our dataset, which contributes to smooth the price series; and ii) despite the high degree of perishability of milk, most of the vertical relationships between farmers and processors are based on long-term contracts. Second, in both markets, the entire adjustment process occurs on the consumer price, a result consistent with the literature. In fact, (see also Table 1, fifth column) the lion's share of PT-related works found causality running from upstream levels to retailers, not vice versa. Therefore, only retail prices adjust when upstream prices change, whereas the latter are often exogenous and do not adjust to changes in consumer prices. However, the magnitude and the speed of the adjustment to a new equilibrium differ in both markets, as both are characterized by different market structures. In the conventional market, the higher retailer-concentration may oblige distributors to readjust quickly to the equilibrium, since it would be easier for the consumer to switch from one retailer to another. In 
the organic market, the supermarkets' market share is less significant, and alternative marketing channels are available, generating a slower adjustment since heterogeneous distributors prevent a quick pass-through. Moreover, the null of a slope equal to unity has not been rejected indicating the existence of a competitive behavior. However, results must be interpreted with caution. Assuming constant marketing costs, albeit in line with the literature, may entail attenuation bias, prejudicing the test in favor of perfect competition hypothesis (see Kinnucan and Zhang (2015) for further details).

Short-run dynamics depict a more favorable situation for organic milk, and both the magnitude and the speed of the responses overcome those on the conventional side.

Asymmetries between the last two levels of the supply chain do not appear to exist. However, asymmetries may exist between the farm gate and the other economic agents along the supply chains, which should be explored in the future when reliable data become available. Moreover, the results should be interpreted with caution, as this study was based on scanned data from a single retailer and generalization could be problematic. In any case, this study opens new opportunities for further research, as new studies about price dynamics in quality-differenced products are necessary to understand better how different market and governance structures influence the performance of their respective supply chains. Furthermore, for more efficient pass-through estimates, retailers' costs should be considered in the estimating equation. 


\section{References}

Abdelradi, F., and Serra, T., 2015. Asymmetric price volatility transmission between food and energy markets: The case of Spain. Agricultural Economics, 46(4), 503-513.

Abdulai, A., 2002. Using Threshold Cointegration to Estimate Asymmetric Price Transmission in the Swiss Pork Market. Applied Economics, 34(6), 679-687.

Achayra, R. N., Kinnucan, H. W., and Caudill, S. B., 2011. Asymmetric Farm-Retail Price Transmission and Market Power: a New Test. Applied Economics, 43, 4759-4768.

Acosta, A., and Valdés, A., 2014. Vertical Price Transmission of Milk Prices: Are Small Dairy Producers Efficiently Integrated into Markets? Agribusiness, 30(1), 56-63.

AGCM, 2013. Indagine conoscitiva sul settore della gdo - ic43. Rome.

Amador, O. F., Baumgartner, J., and Cuaresma, J. C., 2010. Milking the Prices: The Role of Asymmetries in the Price Transmission Mechanism for Milk Products in Austria ( No. 378). WIFO Working Papers.

Awokuse, T. O., and Wang, X., 2009. Threshold Effects and Asymmetric Price Adjustments in U.S. Dairy Markets. Canadian Journal of Agricultural Economics/Revue canadienne d'agroeconomie, 57(2), 269-286.

Azzam, A. M., 1999. Asymmetry and rigidity in farm-retail price transmission. American Journal of Agricultural Economics, 81(3), 525-533.

Bailey, D., and Brorsen, B. W., 1989. Price Asymmetry in Spatial Fed Cattle Markets. Western Journal of Agricultural Economics, 14(2), 246-252.

Bakucs, Z., Fałkowski, J., and Fertő, I., 2012. Price transmission in the milk sectors of Poland and Hungary. Post-Communist Economies, 24(3), 419-432.

Balke, S. N., and Fomby, Y. B., 1997. Threshold Cointegration. International Economic Review, 38(3), 627-645.

Ben-Kaabia, B., and Gil, M. J., 2007. Asymmetric price transmission in the Spanish Lamb Sector. European Review of Agricultural Economics, 34(1), 53-80.

Ben-Kaabia, M., and Gil, J. M., 2008. Asimetrías en la Transmisión de Precios en el Sector del Tomate en España. Economía Agraria y Recursos Naturales, 8(1), 57-82.

Bettendorf, L., and Verboven, F., 2000. Incomplete Transmission of Coffee Bean prices: Evidence From the Netherlands. European Review of Agricultural Economics, 27(1), 1-16.

Borenstein, S., Cameron, C. A., and Gilbert, R., 1997. Do Gasoline Prices Respond Asymmetrically to Crude Oil Price Changes? The Quarterly Journal of Economics, 305-339.

Brümmer, B., Von Cramon-Taubadel, S., and Zorya, S., 2009. The impact of market and policy instability on price transmission between wheat and flour in Ukraine. European Review of Agricultural Economics, 36(2), 203-230.

Busse, S., Brümmer, B., and Ihle, R., 2012. Price formation in the German biodiesel supply chain: a Markov-switching vector error-correction modeling approach. Agricultural Economics, 43(5), 545-560. 
Cacchiarelli, L., Lass, D., and Sorrentino, A., 2016. CAP Reform and Price Transmission in the Italian Pasta Chain. Agribusiness, 32(4), 482-497.

Capps, O., and Sherwell, P., 2007. Alternative approaches in detecting asymmetry in farm-retail price transmission of fluid milk. Agribusiness, 23(3), 313-331.

Cavicchioli, D., 2013. Detecting Market Power Along Food Supply Chains: Evidence From the Fluid Milk Sector in Italy ( No. 2013-1). UNIMI.

Chan, K. S., 1993. Consistency and Limiting Distribution of the Least Squares Estimator of a Threshold Autoregressive Model. The Annals of Statistics, 21(1), 520-533.

Chavas, J.-P., and Mehta, A., 2004. Price Dynamics in a Vertical Sector: The Case of Butter. American Journal of Agricultural Economics, 8(4), 1078-1093.

Conforti, P., 2004. Price transmission in selected agricultural markets. FAO Commodity and Trade Policy Research, (7).

Dickey, D., and Fuller, W., 1981. Likelihood Ratio Statistics for Autoregressive Time Series with a Unit Root. Econometrica, 49(4), 1057-1072.

Doornik, J. A., and Hendry, D. F., 1997. Modelling dynamic systems using PcFilm 9 for Windows. London.

Elliott, G., Rothenberg, T. J., and Stock, J. H., 1996. Efficient Tests for an Autoregressive Unit Root. Econometrica, 64(4), 813-836.

Enders, W., and Granger, C. W. J., 1998. Unit-Root Tests and Asymmetric Adjustment With an Example Using the Term Structure of Interest Rates. Journal of Business \& Economic Statistics, 16(3), 304-311.

Engle, R. F., and Granger, C. W. J., 1987. Co-Integration and Error Correction: Representation, Estimation, and Testing. Econometrica, 55(2), 251-276.

Esposti, R., and Listorti, G., 2013. Agricultural price transmission across space and commodities during price bubbles. Agricultural Economics, 44(1), 125-139.

EUROSTAT, 2017. Cows'milk collection and products obtained - annual data. Retrieved July 9, 2017, from http://ec.europa.eu/eurostat/data/database

Federdistribuzione, 2013. Mappa del Sistema Distributivo Italiano.

Gardner, B. L., 1975. The Farm-Retail Price Spreads in a Competitive Food Industry. American Journal of Agricultural Economics, 57(3), 399-409.

Gonano, S., and Mambriani, D., 2014. L'Industria di Trasformazione. In R. Pieri (Ed.), I/ Mercato del Latte. Rapporto 2014 (pp. 213-246). Mlano: FrancoAngeli.

Goodwin, B. K., and Holt, M. T., 1999. Price transmission and asymmetric adjustment in the US beef sector. American Journal of Agricultural Economics, 81, 630-637.

Goychuk, K., and Meyers, W. H., 2014. Black Sea and World Wheat Market Price Integration Analysis. Canadian Journal of Agricultural Economics/Revue canadienne d'agroeconomie, 62(2), 245-261.

Hamilton, J. D., 1994. Time Series Analysis. Princetwon: Princetown Univeristy Press. 
Han, S., Chung, C., and Surathkal, P., 2016. Impacts of Increased Corn Ethanol Production on Price Asymmetry and Market Linkages in Fed Cattle Markets. Agribusiness, 0(0), 1-25.

Hassouneh, I., Serra, T., Bojnec, Š., and Gil, J. M., 2015. Modeling price transmission and volatility spillover in the Slovenian wheat market. International Association of Agricultural Economists Conference, August 9-14, 2015, Milan, Italy.

Huang, S.-Y., and Sexton, R. J., 1996. Measuring Returns to an Innovation in an Imperfectly Competitive Market: Application to Mechanical Harvesting of Processing Tomatoes in Taiwan. American Journal of Agricultural Economics, 78(3), 558-571.

Ihle, R., Brümmer, B., and Thompson, S. R., 2012. Structural change in European calf markets: decoupling and the blue tongue disease. European Review of Agricultural Economics, 39(1), 157-180.

ISTAT, 2018. Materie prime raccolte e prodotti ottenuti dall'industria lattiero-casearia, per tipo di unità produttiva (quantità in quintali) - Anno 2016. Retrieved June 6, 2018, from http://agri.istat.it/

Johansen, S., 1988. Statistical Analysis of Cointegration Vectors. Journal of Economic Dynamics and Control, 12, 231-254.

Juselius, K., 2006. The cointegrated VAR model: methodology and applications. Oxford University Press.

Kim, H., and Ward, R. W., 2013. Price transmission across the U.S. food distribution system. Food Policy, 41, 226-236.

Kinnucan, H. W., and Forker, O. D., 1987. Asymmetry in Farm-Retail Price Transmission for Major Dairy Products. American Journal of Agricultural Economics, 69(2), 285-292.

Kinnucan, H. W., and Zhang, D., 2015. Notes on farm-retail price transmission and marketing margin behavior. Agricultural Economics, 46(6), 729-737.

Kwiatkowski, D., Phillips, P., Schmidt, P., and Shin, Y., 1992. Testing the null hypothesis of stationarity against the alternative of a unit root. Journal of Econometrics, 54(1), 159-178.

Lee, J., and Gómez, M. I., 2013. Impacts of the End of the Coffee Export Quota System on International-to-Retail Price Transmission. Journal of Agricultural Economics, 64(2), 343-362.

Listorti, G., and Esposti, R., 2012. Horizontal price transmission in agricultural markets: Fundamental concepts and open empirical issues. Bio-based and Applied Economics, 1(1), 81-96.

Lloyd, T., 2016. Forty Years of Price Transmission Research in the Food Industry: Insights, Challenges and Prospects. Journal of Agricultural Economics, 68(1), 3-21.

Lloyd, T. a., McCorriston, S., Morgan, C. W., and Rayner, a. J., 2006. Food scares, market power and price transmission: The UK BSE crisis. European Review of Agricultural Economics, 33(2), 119147.

Lutkepohl, H., 2005. New Introduction to Multiple Time Series. Berlin: Springer.

Lütkepohl, H., and Reimers, H.-E., 1992. Impulse response analysis of cointegrated systems. Journal of Economic Dynamics and Control, 16(1), 53-78.

Madau, F. A., Furesi, R., and Pulina, P., 2016. The existence of buyer power in the Italian fresh milk 
supply chain. British Food Journal, 118(1), 70-82.

McCorriston, S., Morgan, C. W., and Rayner, A. J., 1998. Processing Technology, Market Power and Price Transmission. Journal of Agricultural Economics, 49(2), 185-201.

McCorriston, S., Morgan, C. W., Rayner, a J., and Rayner, J. A., 2001. Price Transmission: the Interaction between Market Power and Returns to Scale. European Review of Agricultural Economics, 28(2), 143-159.

McLaren, A., 2015. Asymmetry in Price Transmission in Agricultural Markets. Review of Development Economics, 19(2), 415-433.

Meredith, S., Kölling, A., Busacca, E., and Moeskops, B., 2014. Opportunities and Challanges for the Organic Sector in the CAP and Other Policies. In S. Meredith and H. Willer (Eds.), Organic in Europe. Prospects and Developments. Bruxelles: IFOAM.

Meyer, J., 2004. Measuring market integration in the presence of transaction costs-a threshold vector error correction approach. Agricultural Economics, 31(2-3), 327-334.

Meyer, J., and von Cramon-Taubadel, S., 2004. Asymmetric Price Transmission: A Survey. Journal of Agricultural Economics, 55(3), 581-611.

Peltzman, S., 2000. Prices Rise Faster than They Fall. The Journal of Political Economy, 108(3), 466.

Phillips, P. C. B., and Perron, P., 1988. Testing for a unit root in time series. Biometrika, 75(2), 335346.

Reagan, P. B., and Weitzman, M. L., 1982. Asymmetries in price and quantity adjustments by the competitive firm. Journal of Economic Theory, 27(2), 410-420.

Romeo, M., and Bteich, M. R., 2014. Country Reports. Italy. In S. Meredith and H. Willer (Eds.), Organic in Europe. Prospects and Developments. Bruxelles.

Santeramo, F. G., 2015. Price Transmission in the European Tomatoes and Cauliflowers Sectors. Agribusiness, 31(3), 399-413.

Santeramo, F. G., and Cioffi, A., 2012. The entry price threshold in EU agriculture: Deterrent or barrier? Journal of Policy Modeling, 34(5), 691-704.

Santeramo, F. G., and von Cramon-Taubadel, S., 2016. On Perishability and Vertical Price Transmission: empirical evidences from Italy. Bio Based Applied Economics, 5(2), 199-214.

Sckokai, P., 2014. La Distribuzione al Dettaglio. In R. Pieri (Ed.), I/ Mercato del Latte. Rapporto 2014 (pp. 315-332). Milano: FrancoAngeli.

Sckokai, P., Soregaroli, C., and Moro, D., 2013. Estimating Market Power by Retailers in a Dynamic Framework: The Italian PDO Cheese Market. Journal of Agricultural Economics, 64(1), 33-53.

Serra, T., and Goodwin, B. K., 2003. Price transmission and asymmetric adjustment in the Spanish dairy sector. Applied Economics, 35(18), 1889-1899.

Sexton, R. J., 2013. Market Power, Misconceptions, and Modern Agricultural Markets. American Journal of Agricultural Economics, 95(2), 209-219.

Sexton, R. J., Sheldon, I., McCorriston, S., and Wang, H., 2007. Agricultural trade liberalization and economic development: the role of downstream market power. Agricultural Economics, 36(2), 
$253-270$.

Sexton, R. J., and Zhang, M., 2001. An assessment of the impact of food industry market power on U.S. consumers agribusiness. Agribusiness, 17(1), 59-79.

Shrinivas, A., and Gómez, M. I., 2016. Price transmission, asymmetric adjustment and threshold effects in the cotton supply chain: a case study for Vidarbha, India. Agricultural Economics, $47(4), 435-444$.

Simioni, M., Gonzales, F., Guillotreau, P., and Le Grel, L., 2013. Detecting Asymmetric Price Transmission with Consistent Threshold along the Fish Supply Chain. Canadian Journal of Agricultural Economics/Revue canadienne d'agroeconomie, 61(1), 37-60.

Surathkal, P., Chung, C., and Sungill, H., 2014. Asymmetric Adjustments in Vertical Price Transmission in the US Beef Sector: Testing for Differences among Product Cuts and Quality Grade. Agricultural \& Applied Economics Association's 2014 AAEA Annual Meeting (27-29 July). Minneapolis.

Tekgüç, H., 2013. Oligopoly and Price Transmission in Turkey's Fluid Milk Market. Agribusiness, 29(3), 293-305.

Tifaoui, S., and von Cramon-Taubadel, S., 2016. Temporary Sales Prices and Asymmetric Price Transmission. Agribusiness.

Tiffin, R., and Dawson, P. J., 2000. Structural breaks, Cointegration and the Farm-Retail Price Spread for Lamb. Applied Economics, 32(10), 1281-1286.

Tong, H., 1983. Threshold Models in Non-Linear Time Series Analysis. New York: Springer-Verlag.

Unnevehr, L., Eales, J., Jensen, H., Lusk, J., McCluskey, J., and Kinsey, J., 2010. Food and Consumer Economics. American Journal of Agricultural Economics, 92(2), 506-521.

Verreth, D. M. I., Emvalomatis, G., Bunte, F., Kemp, R., and Oude Lansink, A. G. J. M., 2015. Price Transmission, International Trade, and Asymmetric Relationships in the Dutch Agri-Food Chain. Agribusiness, 31(4), 521-542.

Ward, R. W., 1982. Asymmetry in retail, wholesale and Shipping Point Pricing for Fresh Vegetables. American Journal of Agricultural Economics, 64(2), 205-212.

Willer, H., 2015. Organic Data Network Surveys 2012-2014. Retrieved from www.OrganicDataNetwork.com

Willer, H., Schaack, D., and Lernoud, J., 2017. Organic Farming and Market Development in Europe and the European Union. In H. Willer and J. Lernoud (Eds.), The World of Organic Agriculture. Statistics and Emerging Trends. FiBL, Frick and IFOAM.

Zeng, S., and Gould, B., 2016. Is There Asymmetric Price Transmission in the US Fluid Milk Market? 2016 Annual Meeting, July 31-August 2, 2016, Boston, Massachusetts. Agricultural and Applied Economics Association. 


\begin{tabular}{|c|c|c|c|c|c|c|c|}
\hline Author(s) & Country & Relationship & $\begin{array}{c}\text { Data } \\
\text { Frequency }\end{array}$ & Causality & Main Results & Type of Relationship & $\begin{array}{c}\alpha \\
\text { estimates } \\
\text { (a) }\end{array}$ \\
\hline $\begin{array}{l}\text { (Amador et al., } \\
\text { 2010) }\end{array}$ & Austria & $\begin{array}{l}\text { Farmer- } \\
\text { Retailer }\end{array}$ & Monthly & Farmer->Retailer & $\begin{array}{l}\text { Pass-through rate more than } \\
\text { proportional, no long-run price } \\
\text { homogeneity. Shocks in farmer } \\
\text { price entail persistent effects on } \\
\text { the consumer price }\end{array}$ & Positive Asymmetries & 0.02 \\
\hline $\begin{array}{c}\text { (Capps and } \\
\text { Sherwell, 2007) }\end{array}$ & $\begin{array}{l}\text { U.S. }(7 \\
\text { Cities) }\end{array}$ & $\begin{array}{l}\text { Farmer- } \\
\text { Retailer }\end{array}$ & Monthly & Farmer->Retailer & $\begin{array}{c}\text { Decreasing farm prices: from } 1 \text { to } 6 \\
\text { months for a full shock } \\
\text { transmission; increasing farm } \\
\text { prices: from } 1 \text { to } 3 \text { months }\end{array}$ & Positive Asymmetries & $\begin{array}{l}0.27(+) \\
0.39(-)\end{array}$ \\
\hline $\begin{array}{l}\text { (Zeng and } \\
\text { Gould, 2016) }\end{array}$ & $\begin{array}{l}\text { U.S. }(11 \\
\text { Cities) }\end{array}$ & $\begin{array}{l}\text { Farmer- } \\
\text { Retailer }\end{array}$ & Monthly & $\begin{array}{c}\text { Farmer->Retailer (in } 6 \\
\text { out of } 11 \text { cities) }\end{array}$ & $\begin{array}{l}\text { In the short-run, retail price } \\
\text { responds differently depending on } \\
\text { the sign of the change. In the long- } \\
\text { run, it takes several months for the } \\
\text { retail price to reflects the farmer } \\
\text { price change }\end{array}$ & Positive Asymmetries & 0.14 \\
\hline $\begin{array}{l}\text { (Bakucs et al., } \\
\text { 2012) }\end{array}$ & $\begin{array}{l}\text { Poland and } \\
\text { Hungary }\end{array}$ & $\begin{array}{l}\text { Farmer- } \\
\text { Retailer }\end{array}$ & Monthly & $\begin{array}{l}\text { Farmer->Retailer } \\
\text { (Hungary); } \\
\text { Retailer->Farmer } \\
\quad \text { (Poland); }\end{array}$ & $\begin{array}{l}\text { Different market structures entail } \\
\text { different PT dynamics }\end{array}$ & $\begin{array}{l}\text { Positive Asymmetries (Poland) } \\
\text { Symmetric (Hungary) }\end{array}$ & $\begin{array}{l}0.22 \\
0.20\end{array}$ \\
\hline $\begin{array}{l}\text { (Awokuse and } \\
\text { Wang, 2009) }\end{array}$ & U.S. & $\begin{array}{l}\text { Farmer- } \\
\text { Retailer }\end{array}$ & Monthly & Farmer <-> Retailer & $\begin{array}{l}\text { The presence of asymmetric } \\
\text { dynamics should be taken into } \\
\text { serious consideration when } \\
\text { designing new policy reforms }\end{array}$ & Negative Asymmetries & $\begin{array}{l}0.31(-) \\
0.04(+)\end{array}$ \\
\hline $\begin{array}{l}\text { (Acosta and } \\
\text { Valdés, 2014) }\end{array}$ & Panama & $\begin{array}{l}\text { Farmer- } \\
\text { Wholesaler }\end{array}$ & Monthly & Farmer->Wholesaler & $\begin{array}{c}\text { The speed of convergence is } \\
\text { "moderately slow" (i.e., } 9 \% \text { of the } \\
\text { shock is transmitted for each } \\
\text { period }\end{array}$ & Negative Asymmetries & $\begin{array}{c}0.09 \\
0.32(-)\end{array}$ \\
\hline $\begin{array}{c}\text { (Serra and } \\
\text { Goodwin, 2003) }\end{array}$ & Spain & $\begin{array}{l}\text { Farmer- } \\
\text { Retailer }\end{array}$ & $\begin{array}{l}\text { Weekly and } \\
\text { Monthly }\end{array}$ & $\begin{array}{l}\text { Farmer->Retailer } \\
\text { (weekly freq.); farmer } \\
\text { prices more elastic } \\
\text { retail prices changes } \\
\text { (monthly freq.) }\end{array}$ & $\begin{array}{c}\text { Symmetric PT in highly perishable } \\
\text { dairy product prices. Slow } \\
\text { adjustment of retail prices to farm } \\
\text { price shocks }\end{array}$ & $\begin{array}{c}\text { Symmetric (for high perishable } \\
\text { dairies); Asymmetric (for long } \\
\text { shelf-life dairies) }\end{array}$ & - \\
\hline
\end{tabular}

(a) Absolute values. When displayed, ' + ' and '-' signs refer to increasing and decreasing margins, respectively. Otherwise, the coefficient refers to linear VECM estimation. We reported only statistically significant coefficients

Source: Authors' personal elaboration 
Table 2 - Johansen Co-integration test

\begin{tabular}{|c|c|c|c|c|c|c|c|}
\hline$p-r^{a}$ & $r^{b}$ & $\lambda_{\text {trace }}$ & C.V. & $\mathrm{p}$-Value & $\lambda_{\max }$ & C.V. & $\mathrm{p}$-Value \\
\hline \multicolumn{8}{|c|}{ Organic Milk System } \\
\hline 2 & 0 & 22.362 & 20.164 & 0.023 & 14.09 & 15.892 & 0.094 \\
\hline 1 & 1 & 8.272 & 9.142 & 0.074 & 8.272 & 9.165 & 0.074 \\
\hline \multicolumn{8}{|c|}{ Conventional Milk System } \\
\hline 2 & 0 & 39.686 & 20.164 & 0.00 & 18.217 & 15.892 & 0.021 \\
\hline 1 & 1 & 6.366 & 9.142 & 0.249 & 4.362 & 9.165 & 0.361 \\
\hline
\end{tabular}

$\mathrm{a}, \mathrm{b}$ Number of common trends, where $\mathrm{p}$ is the number of variables and $r$ the number of cointegrating relationships, the rank of the matrix $\Pi$

Source: Authors' elaboration

Table 3 - Threshold Models Estimates

\begin{tabular}{|c|c|c|c|c|}
\hline & $T_{A R^{a}}$ & TAR consistent ${ }^{\mathrm{a}(*)}$ & M-TAR ${ }^{a}$ & M-TAR consistent ${ }^{\mathrm{a}\left({ }^{*}\right)}$ \\
\hline \multicolumn{5}{|c|}{ Organic Milk System } \\
\hline & -0.111 & -0.0742 & -0.141 & -0.354 \\
\hline$\rho_{1}$ & $(0.059)$ & $(0.062)$ & $(0.061)$ & $(0.107)$ \\
\hline & -0.159 & -0.193 & -0.117 & -0.105 \\
\hline$\rho_{2}$ & $(0.069)$ & $(0.065)$ & $(0.067)$ & (0.049) \\
\hline $\mathbf{\tau}$ & 0 & 0.013 & 0 & 0.003 \\
\hline $\boldsymbol{\Phi}_{u}$ and $\boldsymbol{\Phi}_{u}^{*}\left(\rho_{1}=\rho_{2}=\mathbf{0}\right)^{\mathrm{c}}$ & 3.679 & 4.628 & 3.541 & 6.366 \\
\hline F-test $\left(\rho_{1}=\rho_{2}\right)^{d}$ & 0.352 & 1.273 & $\begin{array}{r}0.088 \\
\text { C.V. }\end{array}$ & 5.471 \\
\hline $\boldsymbol{\Phi}_{\boldsymbol{u}}$ and $\boldsymbol{\Phi}_{\boldsymbol{u}}^{*}$ & 5.519 & 7.029 & 6.225 & 8.567 \\
\hline F-test & 3.374 & 6.909 & 3.682 & 8.408 \\
\hline \multicolumn{5}{|c|}{ Conventional Milk System } \\
\hline$\rho_{1}$ & $\begin{array}{l}-0.179 \\
(0.104)\end{array}$ & $\begin{array}{l}-0.122 \\
(0.107)\end{array}$ & $\begin{array}{l}-0.153 \\
(0.096)\end{array}$ & $\begin{array}{l}-0.155 \\
(0.086)\end{array}$ \\
\hline & -0.230 & -0.275 & -0.299 & -0.419 \\
\hline$\rho_{2}$ & $(0.106)$ & $(0.100)$ & (0.129) & (0.179) \\
\hline$\tau$ & 0 & 0.012 & 0 & -0.002 \\
\hline $\boldsymbol{\Phi}_{u}$ and $\boldsymbol{\Phi}_{u}^{*}\left(\rho_{1}=\rho_{2}=\mathbf{0}\right)^{\mathrm{c}}$ & 3.402 & 4.047 & 3.804 & 4.333 \\
\hline F-test $\left(\rho_{1}=\rho_{2}\right)^{d}$ & 0.138 & 1.273 & $\begin{array}{r}0.846 \\
\text { C.V. }^{\text {b }}\end{array}$ & 1.778 \\
\hline $\boldsymbol{\Phi}_{\boldsymbol{u}}$ and $\boldsymbol{\Phi}_{\boldsymbol{u}}^{*}$ & 5.570 & 6.817 & 5.924 & 8.214 \\
\hline F-test & 3.234 & 6.384 & 3.577 & 8.408 \\
\hline
\end{tabular}

\footnotetext{
Values between brackets are the standard errors

${ }^{a}$ AIC selected seven lags for the $\Delta \widehat{\mu}_{t-i}\left(p_{\text {max }}=10\right)$ for Organic and four lags for Conventional models, respectively

${ }^{(*)}$ For the two models, the threshold value was estimated through Chan's methodology

${ }^{b}$ Critical Values were simulated for $5 \%$ sig. level (1,000 Monte Carlo simulations)

${ }^{\mathrm{c}}$ Test for threshold cointegration

${ }^{\mathrm{d}}$ Test for asymmetric price adjustment
}

Source: Authors' elaboration 
Table 4 - Organic Milk System: Results from Cointegration Analysis, Restrictions on Deterministic, Long- and Short-run Coefficients

\begin{tabular}{ccc} 
& Organic Milk System & \\
Unrestricted cointegrating vector & $P_{s}-0.51 P_{\mathrm{P}}-0.40 \mu_{1}^{\prime}-0.04 D_{s, t}=Z_{t}$ \\
Linear Restrictions & LR-Statistic & P-Value \\
Long-run Homogeneity $\boldsymbol{\beta}(\mathbf{1}, \mathbf{- 1})$ & 5.45 & 0.020 \\
Weak Exogeneity $\boldsymbol{\alpha}_{\boldsymbol{P p}}=\mathbf{0}$ & 0.131 & 0.720 \\
Exclusion Test $^{\mathrm{a}} \boldsymbol{\mu}_{\mathbf{1}}^{\prime}=\mathbf{0}$ & 4.520 & 0.033 \\
Exclusion Test $^{\text {b }} \boldsymbol{D}_{\boldsymbol{s , t}}=\mathbf{0}$ & 4.880 & 0.027 \\
& Conventional Milk System & \\
Unrestricted cointegrating vector & $P_{s}-0.72 P_{\mathrm{p}}-0.28=Z_{t}$ \\
Long-run Homogeneity $\boldsymbol{\beta}(\mathbf{1}, \mathbf{- 1})$ & 3.49 & 0.062 \\
Weak Exogeneity $\boldsymbol{\alpha}_{\boldsymbol{P} \boldsymbol{p}}=\mathbf{0}$ & 0.04 & 0.85 \\
Restricted cointegrating vector & \multicolumn{2}{c}{$P_{s}-P_{\mathrm{p}}-0.24=Z_{t}$} \\
Retail Margin & $\left(e^{0.24}-1\right) \times \ln P_{\mathrm{p}} \times 100=27,5 \%$
\end{tabular}

\footnotetext{
${ }^{a, b}$ The last two rows refer to the exclusion tests, which show whether the deterministic terms, i.e., the constant and the dummy, enter the cointegration space. The model is well-specified since for neither parameter does the LR statistic accept the null hypothesis of exclusion.
}

Source: Authors' elaboration 


\section{Appendix}

Table A1- Unit-Root Tests

\begin{tabular}{|c|c|c|c|c|c|}
\hline \multicolumn{3}{|c|}{$\begin{array}{l}\text { Conventional Milk System } \\
\text { ADF-GLS Unit Root }\end{array}$} & \multicolumn{3}{|c|}{$\begin{array}{l}\text { Organic Milk System } \\
\text { ADF-GLS Unit Root }\end{array}$} \\
\hline With Constant & $\left(P_{p}\right)$ & $\left(P_{S}\right)$ & With Constant & $\left(P_{p}\right)$ & $\left(P_{S}\right)$ \\
\hline Tau & -0.194 & -0.235 & T-Stat & -0.0757 & -0.316 \\
\hline P-Value & 0.616 & 0.601 & P-value & 0.657 & 0.572 \\
\hline MAIC* & 1 & 1 & MAIC* & 2 & 2 \\
\hline \multicolumn{3}{|c|}{ PP Test } & \multicolumn{3}{|c|}{ PP Test } \\
\hline Z_t & -1.321 & -2.108 & Z_t & -0.557 & -1.297 \\
\hline P-Value & 0.619 & 0.242 & P-Value & 0.876 & 0.630 \\
\hline \multicolumn{3}{|c|}{ KPSS Test } & \multicolumn{3}{|c|}{ KPSS Test } \\
\hline T-Stat & 7.095 & 5.776 & T-Stat & 4.827 & 4.078 \\
\hline P-Value & $<0.01$ & $<0.01$ & P-value & $<0.01$ & $<0.01$ \\
\hline Lag Truncation & 1 & 1 & Lag Truncation & 2 & 2 \\
\hline \multicolumn{3}{|c|}{ ADF-GLS Unit Root } & \multicolumn{3}{|c|}{ ADF-GLS Unit Root } \\
\hline With Constant & $\left(\Delta P_{p}\right)$ & $\left(\Delta P_{S}\right)$ & With Constant & $\left(\Delta P_{p}\right)$ & $\left(\Delta P_{s}\right)$ \\
\hline Tau & -4.630 & -9.484 & Tau & -7.771 & -8.458 \\
\hline P-Value & 0.000 & 0.000 & P-Value & 0.000 & 0.000 \\
\hline MAIC* & 5 & 4 & MAIC* & 1 & 4 \\
\hline \multicolumn{3}{|c|}{ PP Test } & \multicolumn{3}{|c|}{ PP Test } \\
\hline Z_t & -11.642 & -9.100 & Z_t & -11.642 & -13.169 \\
\hline P-Value & 0.000 & 0.000 & P-Value & 0.000 & 0.000 \\
\hline \multicolumn{3}{|c|}{ KPSS Test } & \multicolumn{3}{|c|}{ KPSS Test } \\
\hline T-Stat & 0.043 & 0.096 & T-Stat & 0.083 & 0.303 \\
\hline P-Value & $>0.10$ & $>0.10$ & P-Value & $>0.10$ & $>0.10$ \\
\hline Lag Truncation & 4 & 4 & Lag Truncation & 4 & 4 \\
\hline
\end{tabular}

*Modified Akaike Information Criterion, see Ng and Perron (2001) for more details.

Source: Authors' elaboration 
Figure 1 - The Relationship between Processor and Retailer Prices
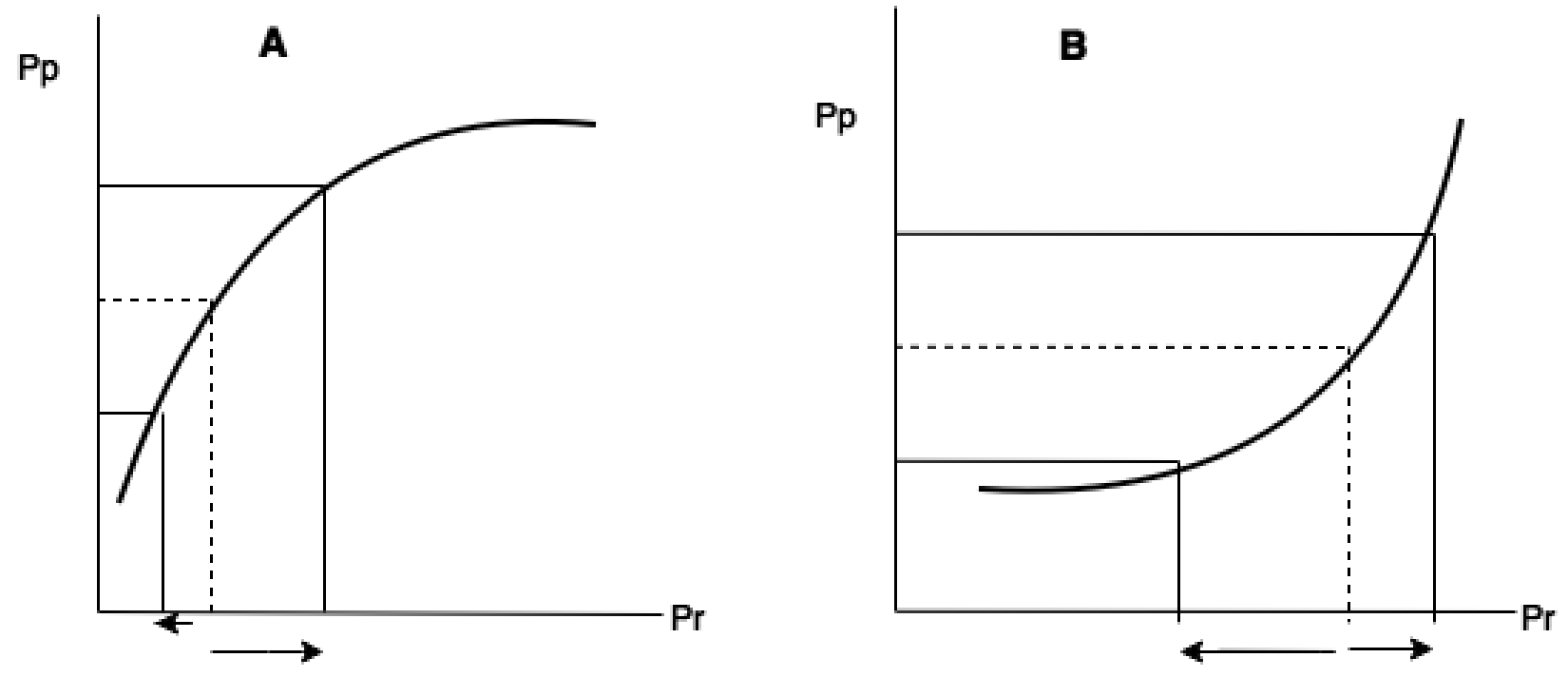

Source: Authors' elaboration based on McLaren (2015) 
Figure 2 - The Organic (left) and Conventional (right) Milk Systems (prices expressed in logarithms)
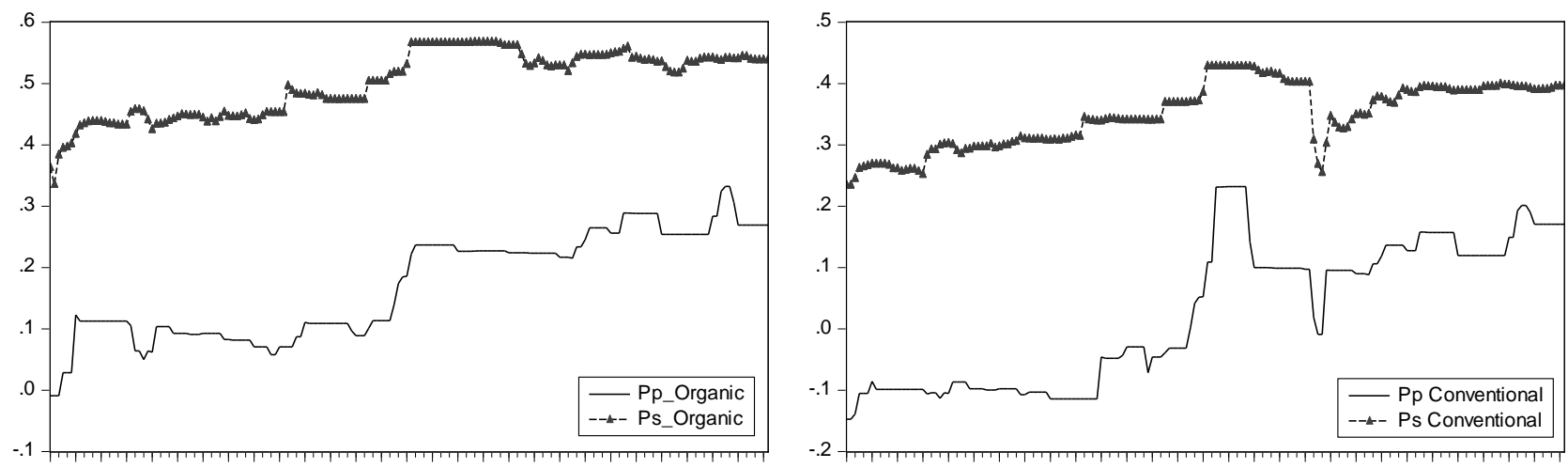

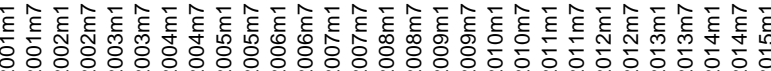
Source: Authors' elaboration

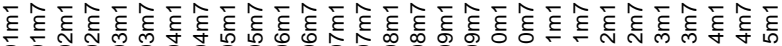

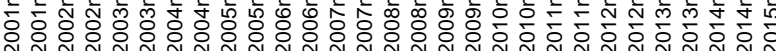


Figure 3 - Conventional (Upper-panels) and Organic (Lower-panels) System: Orthogonalized IRFs for

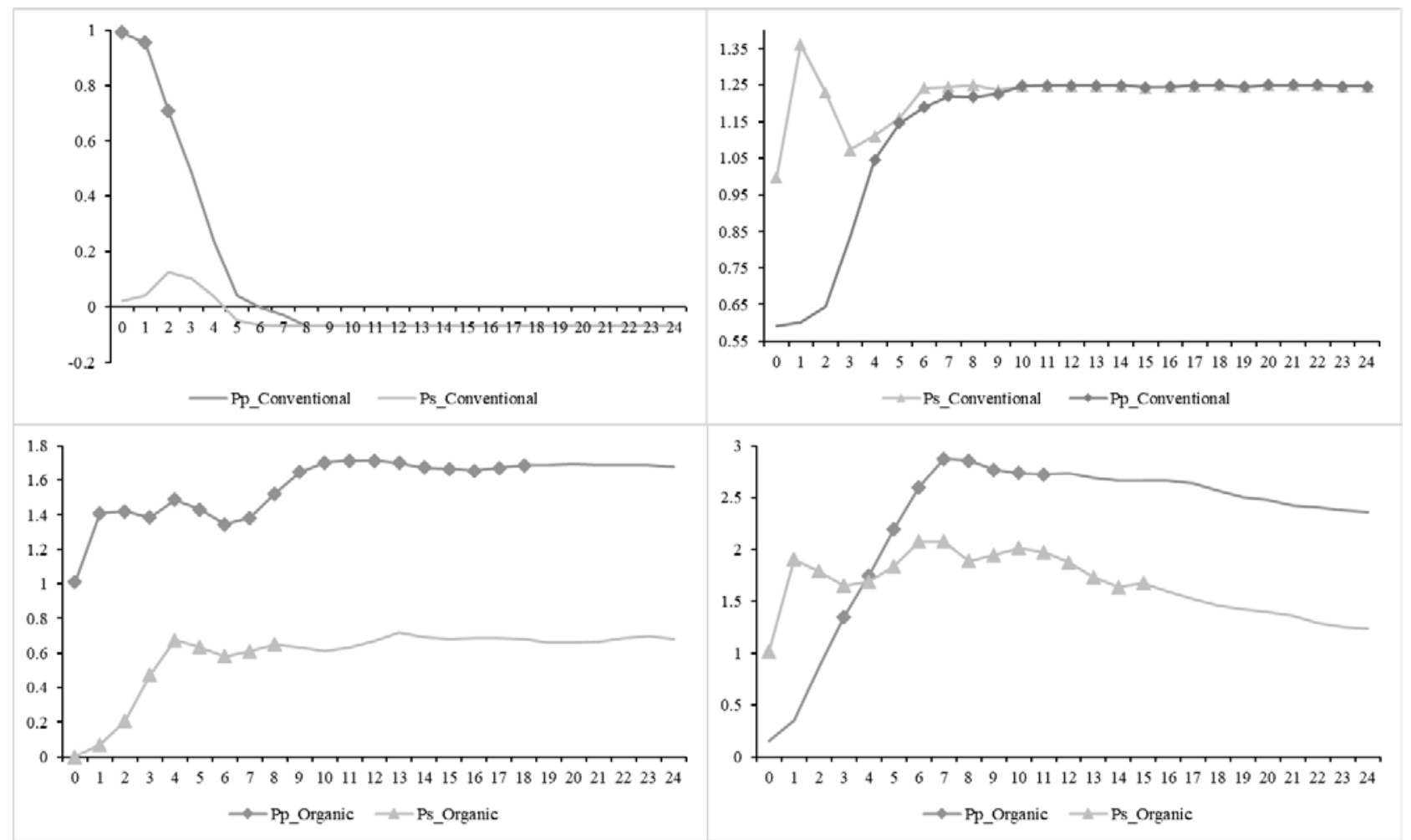

shocks to both Pp (Left panel) and Ps (Right panel)

*A mark shows when the response is significant Source: Authors' elaboration 